\title{
Clinical, tomographic, and postmortem aspects of a rare congenital Dicephalus Monauchenos Iniodymus in a Nelore calf produced in vitro from Brazil - case report
}

\author{
[Aspectos clínicos, tomográficos e pós-morte de um raro Dicephalus Monauchenos Iniodymus congênito em um \\ bezerro Nelore produzido in vitro no Brasil - relato de caso]
}

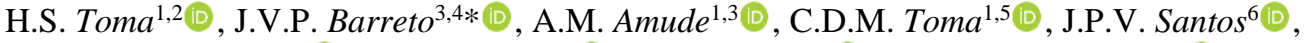

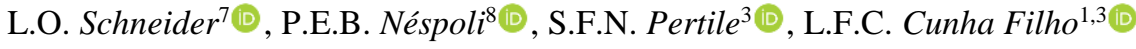 \\ ${ }^{1}$ Universidade de Cuiabá, Faculdade de Medicina Veterinária, Cuiabá, MT, Brasil \\ ${ }^{2}$ Universidade Federal de Lavras, Lavras, MG, Brasil \\ ${ }^{3}$ Universidade Pitágoras Unopar, Arapongas, PR, Brasil \\ ${ }^{4}$ Graduate, Universidade Estadual de Londrina, Londrina, PR, Brasil \\ ${ }^{5}$ Centro Universitário de Lavras, Lavras, MG, Brasil \\ ${ }^{6}$ Graduate, Universidade de Cuiabá, Cuiabá, MT, Brasil \\ ${ }^{7}$ Instituto Nacional de Investigación Agropecuaria, Tacuarembó, Uruguai \\ ${ }^{8}$ Universidade Federal do Mato Grosso, Cuiabá, MT, Brasil
}

\begin{abstract}
The aim of this work was to report the occurrence of dicephalus iniodymus monauchenos in a Nellore newborn. A three-days old calf, from in vitro production, with duplication of the head and a history of cesarean birth was attended. On physical examination, the dicephalus, iniodymus and monauchenos, which were almost the same size and shape, had four eyes and four ears. Computed tomography showed the presence of two skulls fused with a common occipital foramen, two nasopharynxes, oropharynxes with the presence of a cleft lip and a cleft palate in the right head, which continued in a single esophagus and a single trachea. At necropsy, the presence of duplication of the cerebrum and cerebellum was observed, with union of the parts in the region of the trapezoid body of the brainstem and continued as a single spinal cord. This study characterizes the clinical, tomographic, and necropsy findings of a dicephalus Nelore neonate.
\end{abstract}

Keyword: dicephaly, reproductive biotechnologies, cleft palate, cleft lip, monauchenos

\section{RESUMO}

O objetivo deste trabalho foi relatar a ocorrência de Dicephalus Iniodymus Monauchenos em um neonato da raça Nelore de produção in vitro. Foi atendida uma fêmea bovina, de três dias de idade, com duplicação das cabeças e histórico de nascimento por meio de cesariana. No exame físico, observou-se a dicefalia, Iniodymus e Monauchenos, apresentando quatro olhos e quatro orelhas. Na tomografia computadorizada, constatou-se a presença de dois crânios fundidos com um forame occipital comum, duas nasofaringes, orofaringes com presença de lábio leporino e fenda palatina na cabeça direita, que continuavam em um único esôfago e em uma única traqueia. Na necropsia, observou-se a presença de duplicação do encéfalo e cerebelo, com união das partes na região do corpo trapezoide do tronco encefálico, que continuavam como uma única medula espinhal. Este estudo caracteriza os achados clínicos, tomográficos e de necropsia de um neonato Nelore dicefálico.

Palavras-chave: dicefalia, biotecnologias reprodutivas, fenda palatina, lábio leporino, Monauchenos

\section{INTRODUCTION}

Congenital duplications (anomalous twins, double monsters or defective twinnings) in domestic animals stimulated man's curiosity due to the strangeness of the abnormalities and the

*Corresponding author: jose.proni@hotmail.com

Submitted: March 1, 2021. Accepted: May 24. 2021. frequency of descriptions in veterinary books about horses, cattle, buffaloes, sheep, pigs, canines and felines (Salami et al., 2011). Among these species, congenital duplication is more common in cattle, with approximately one case per 25.000 to up to 100.000 normal births 
(Ahmed et al., 2015) representing between 2.2 to $10 \%$ (Biasibetti et al., 2011) or up to $17.5 \%$ of all congenital anomalies in cattle (Hiraga et al., 1989; Madarame et al., 1993). Duplication of the cranial portion of the fetus is more common than the caudal portion (Ahmed et al., 2015) and the skull is the most commonly affected part, with an incidence of $64 \%$ (Gülbahar et al., 2005) up to $75 \%$ of all the congenital duplication cases (Madarame et al., 1993; Biasibetti et al., 2011).

All united twins are monozygotic in origin and represents an incomplete division of the embryo into two components during the early development stage (Ahmed et al., 2015) and the etiology of the congenital duplications can be genetic, environmental, or resulting from interactions between these (Mazzullo et al., 2003; Gülbahar et al., 2005). The use of in vitro production for breeding cattle are also related to the birth of calves with congenital anomalies (Branco et al., 2017; Torres et al., 2013).

Diprosopus and dicephalus are described as abnormalities of incomplete separation of the heads resulting from defective embryonic development (Mazzullo et al., 2003; Ahmed et al., 2015) and represents a series of changes ranging from the presentation of two snouts to individuals with two complete heads (Salami et al., 2011). The name Diprosopus refers to a single body and a single head, showing a spectrum of duplications of craniofacial structures with great variability in their union site and degree of organ sharing (Mazzullo et al., 2003; Biasibetti et al., 2011; Salami et al., 2011), and Dicephalus refers to a two completely separated heads and the duplication of internal structures with several simultaneous defects such as cleft palate, abnormal ossification of the sternum, torticollis, hypoplasia of the larger colon and abnormalities of the heart and great vessels (Hiraga et al., 1989; Biasibetti et al., 2011), arthrogryposis (Gülbahar et al., 2005), spina bifida, spinal dysraphism and, finally, the Arnold-Chiari malformation (Madarame et al., 1993; Gülbahar et al., 2005; Biasibetti et al., 2011) which may be related to cerebellar herniation due to the larger diameter of the foramen magnum and smaller size of the posterior fossa (Gülbahar et al., 2005).

The aim of the present study is to describe the rare occurrence of Dicephalus Iniodymus
Monauchenes in a Nelore calf produced in vitro, its clinical, tomographic and necropsy aspects.

\section{MATERIAL AND METHODS}

A three-days old female calf, Nelore breed, from in vitro production, was seen at the Veterinary Hospital. In the anamnesis, the owner reported that the primiparous cow had dystocia for 18 hours and underwent cesarean surgery. Immediately after the cesarean section, the newborn was alive, active, conscious, kept in sternal recumbency, had suction reflex on both snouts and had ingested the mother's colostrum through a bottle, but surprisingly had two duplicated heads.

This work was approved by the Ethics Committee for the Use of Animals and internationally recognized high standards of veterinary clinical care for the individual patient were followed. This work involved the use of non-experimental animals (owned) and an informed consent (either verbal or written) was obtained from the owner or legal custodian. The veterinary hospital's medical record has a term where the owner authorizes the use of clinical and laboratory data for use in scientific studies and works, a term evaluated by the Ethics Committee for the Use of Animals.

\section{CASUISTRY}

Physical examination of the calf revealed two partially duplicated heads (diprosopus / dicephalic) in one neck (monauchenes), four eyes (tetraophthalmus), four ears of which the two medial ears merged into a single auricular pavilion and moved normally, with different tympanic bullae, a pair of mandibles and the right head had a cleft lip and cleft palate. The animal remained in sternal recumbency, although it lost its balance when trying to stand still, due to the misalignment of the left head that destabilization of the the calve.

The 4 eyes showed movement of blinking and moved simultaneously. During artificial milk feeding, the bottle was directed to the left head, as it did not present any morphological changes, although synchronous suction movements were observed in both snouts. 

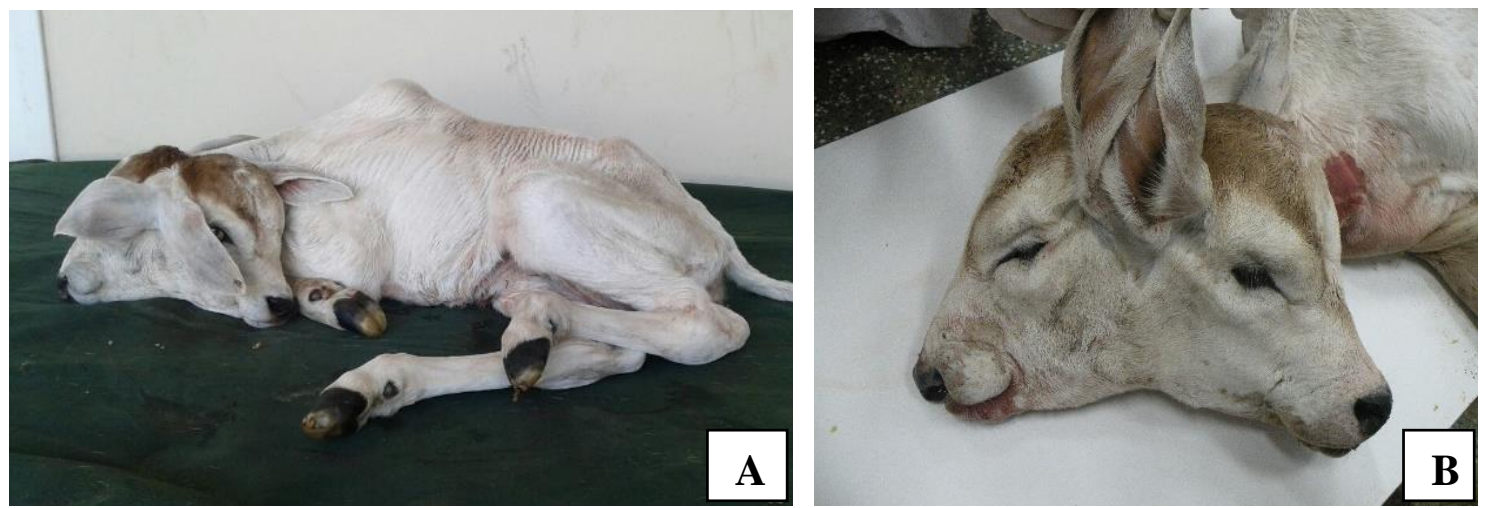

Figure 1. Nellore calf with dicephaly. A: Animal permanently in sternal recumbency; B: Presence duplicated heads (diprosopus / dicephalic) in one neck (monauchenes), four eyes (tetraophthalmus) and four ears.

Complete blood count and serum concentrations of aspartate aminotransferase activity, alkaline phosphatase, creatine phosphokinase, gammaglutamyltransferase, albumin, bilirubin, total calcium, cholesterol, creatinine, total protein, sodium, triglycerides and urea were within normal values. RT-PCR was performed from the sequence of the untranslated region (5'UTR) of the Pestivirus spp. genome (Vilček et al., 1994) of a whole blood sample, which was negative. Even with all the clinical care for food, comfort and well-being, the animal's clinical condition worsened, leading to death on the fifth day of life, when computed tomography (CT) and necropsy were performed.

Computed tomography showed two skulls fused with a common occipital foramen, but the distances between the condyles of the occipital
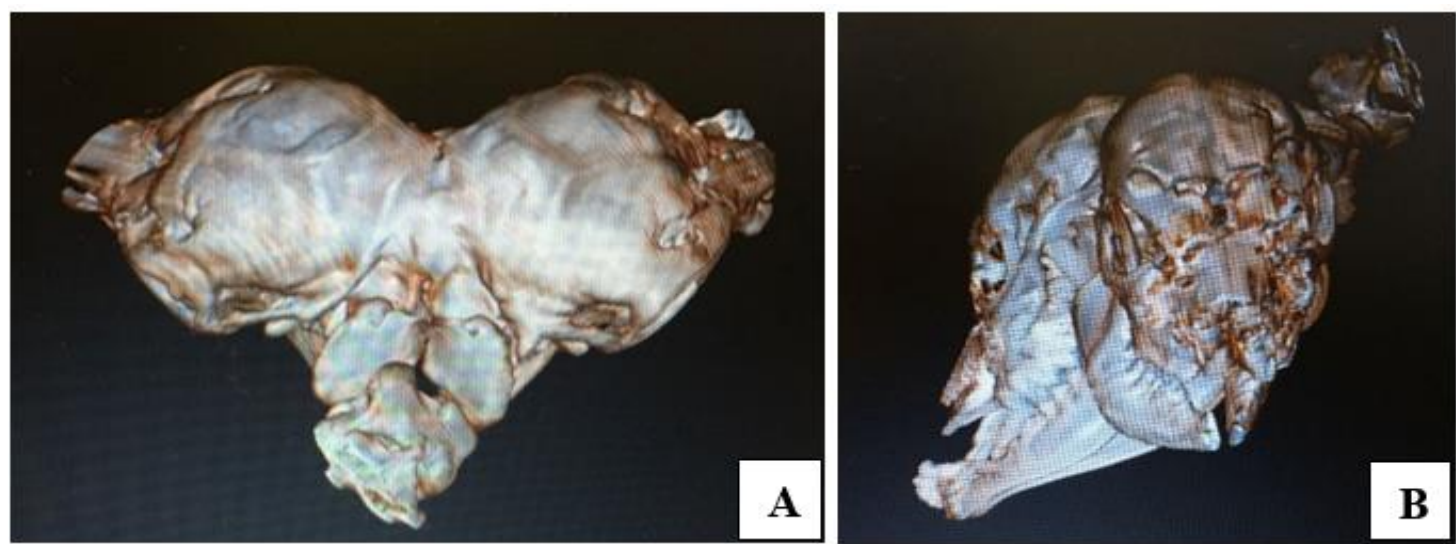

Figure 2. Computed tomography showing reconstruction of skull bone parts and atlas. A: Dorsal view showing the fusion of the two skulls in the occipital region and the presence of a single atlas; B: Cranial view showing the fusion of the mandible and malformation of the maxillary, nasal and lacrimal bone of the right head on the medial face. 
At necropsy, there was a duplication of the head structures, including most part of the skull bones, which fuses at the center, as well as a duplication of the mandible. At the opening of the skull, two Sella Turcica were observed on the floor of the skullcap, but only one foramen magnum articulated to the first cervical vertebra of normal conformation. In addition, there was duplicity of the eyeballs, which totaled four anatomically independent structures. Four ears were also observed, were the two medial were fused. Each head had a tongue that joined with its roots and connected to the equally duplicated rostral portion of the pharynx. Queilosquise and palatosquise were also observed on the right head. The larynx was normal and the pharynx was narrowed and opened in a single trachea and esophagus, respectively. The central nervous system was composed of two completely separated brains, including the hemispheres, two cerebellums, up to the region of the trapezoid body of the brainstem, where the two brains joined and continued as a single spinal cord. The spine was not duplicated, so the skull had a single foramen magnum that articulated in a single atlas. The cerebellums were hypoplasics and partially herniated (Arnold Chiari) towards the foramen magnum, due to the inadequate development of the cranial cavities, as observed by the smaller posterior fossa that was reduced and duplicated. The heart was not duplicated, but there was a interventricular septum malformation that allowed the communication between ventricles. The other thoracic and abdominal viscera were not duplicated and all limbs were also normal.

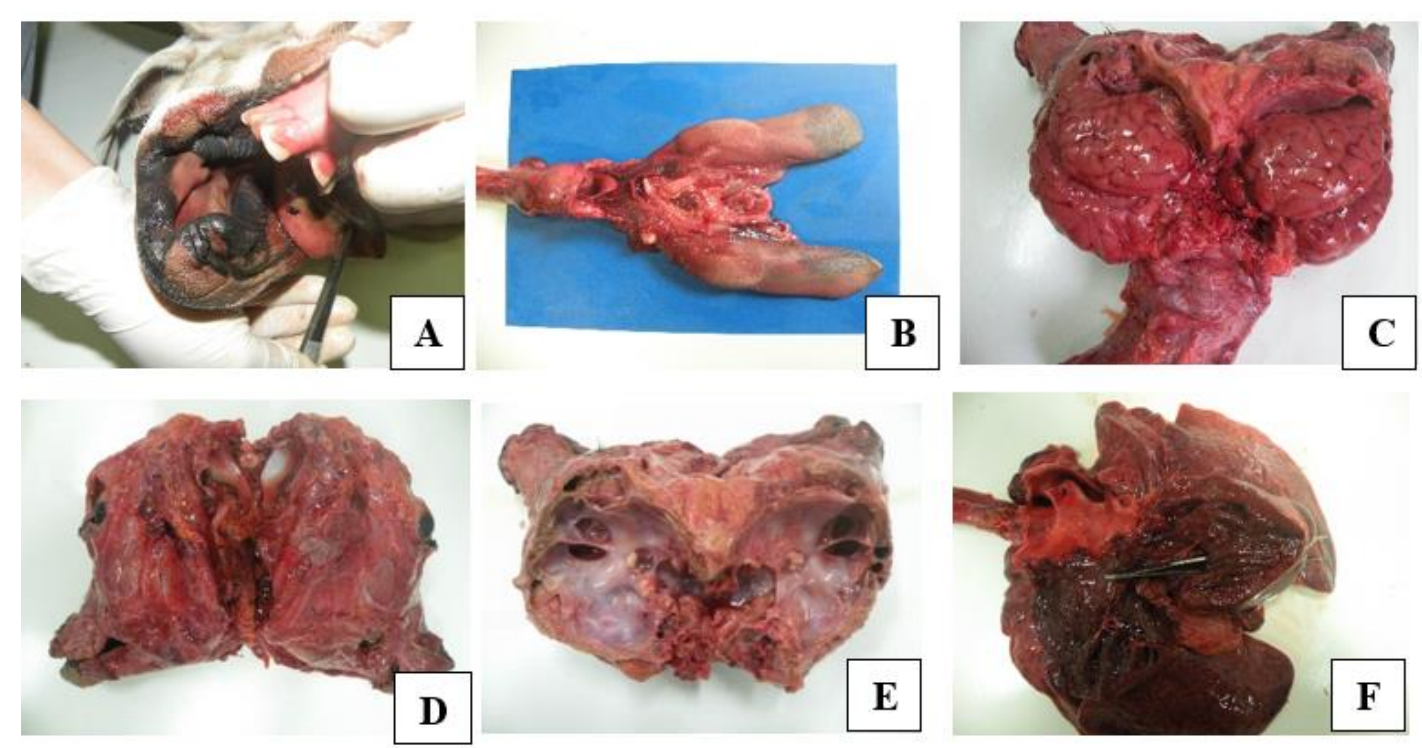

Figure 3. Necropsy of the dicephalic calf. A: Right head showing queilosquise and palatosquise of the right head; B: Duplicated tongues that join at their base and continue in a single trachea and esophagus; C: Presence of four cerebral hemispheres and two hypoplasics cerebellums; D: Presence of a single foramen magnum; E: Two Sella Turcica and two smaller posterior pits; F: Heart showing interventricular septum malformation (indicated by the clamp).

\section{DISCUSSION}

The calf of this report presented two distinct skulls, fused in the region of the foramen magnum and the presence of complete duplication of the brain, two hypoplasic cerebellums and the fusion of the central nervous system occurred at the beginning of the spinal cord (trapezoid body), and due to these characteristics, the studied animal can be classified as dicephalic, according to the classification presented by Biasibetti et al. (2011) which suggests that in a diprosopus animal, the central nervous system fusion may occur in the midbrain region or cranially.

Dicephalus in cattle is classified into five types, according to its macroscopic findings (Hiraga et 
al., 1989), thus, the present case was classified as Hiraga type 5 and presented four eyes, four ears, two mandibles, four cerebral hemispheres, two cerebellums and two pituitary glands, as well as the report of (Madarame et al., 1993) who observed the same abnormalities in a Japanese Black calf. In a report by Gülbahar et al. (2005) about a newborn calf by the Holstein breed, classified as Hiraga type 4, the only difference was the presence of 3 ears.

According to terminologies used by Mehmood et al. (2014) the dicephalic fetus can be classified into: atlodymus (two complete and separate skulls and single neck), iniodymus (two skulls with fusion in the occipital region) and derodymus (two complete and separate skulls with two separate necks). In this report, the iniodymus classification is observed due to the existence of two fused heads in the occipital region and the presence of a single neck that is attributed to the nomenclature of monauchenes (Salami et al., 2011).

There are several theories for the etiology of the conjoined twins, one of which is the imperfect twinning fission, which in the clinical findings of the present calf seems to be consistent with the hypothesis that a single initial embryonic axis was divided (Salami et al., 2011).

Several factors may be involved in the etiology of dicephaly, such as viral infections, toxicosis, nutritional deficiency, genetics and environmental factors (Mazzullo et al., 2003; Gülbahar et al., 2005). The heifer was negative for Pestivirus spp., which is known to induce nervous system congenital anomalies (Gülbahar et al., 2005).

Genetic defects can result in pathological abnormalities due to mutant genes, particularly recessive genes, or chromosomal aberrations (Mazzullo et al., 2003; Biasibetti et al., 2011; Salami et al., 2011). It is well-known that the use of biotechnologies for breeding cattle, such as in vitro production, as used to make the calve of this report, may result in congenital anomalies (Farin et al., 2006; Torres et al., 2013). Despite being a process that is not completely understood, it is possible that anomalies occur due to errors at critical periods of in vitro embryo preimplantation, resulting in wrong epigenetic patterns, which affect the imprinted gene expression (Torres et al., 2013).

In a study investigating the role of inbreeding as a possible cause of diprosopia, Bähr et al. (2004) concluded that this congenital malformation could be genetically influenced by numerous genes and that inbreeding could be an important cause. Besides that, Schulze et al. (2006), reporting several cases of cranial duplication in Holstein calves in Germany, they verified a family bond associated with this abnormality and suggested an oligogenic inheritance.

No association of breed related to cranial duplication has been described, although Holstein and Hereford calves appear to be most frequently affected (Bähr et al., 2004; Schulze et al., 2006; Biasibetti et al., 2011), and there are some reports in the Nellore breed (Branco et al., 2017), which is one of the breeds that most uses assisted reproduction techniques, such as the production of embryos in vitro that gave rise to the calf in this report, which may be a factor related to the birth of calves with congenital anomalies (Branco et al., 2017).

In animals with cranial duplication, diprosopus usually has unaffected or normal internal organs. This is different from what is seen in most cases of dicephalias in which duplication almost always involves internal structures (Salami et al., 2011). Compared to diprosopus, dicephalus is more likely to be associated with a complex of cardiovascular abnormalities (Biasibetti et al., 2011). In the present case, the distribution of the cranial and caudal arteries to the calf's heart were normal and the large blood vessels were also normal, but abnormalities were observed in the heart represented by the defect in the interventricular septum. No other chest and abdominal abnormalities, as well as in the limbs, were found in the studied animal. On tomography, some bone changes observed, such as both posterior fossae with reduced and flat size, increased diameter of the foramen magnum and a slight alteration in the size and shape of the occipital, are possible causes of reduction in the size and fusion of the two posterior fossae, coinciding with hypoplasia and discrete herniation of the cerebellum (Arnold Chiari). 


\section{CONCLUSION}

This case report characterizes the main changes through clinical signs, computed tomography and necropsy of a bovine neonate of the Nelore breed produced in vitro, and suggests further investigations to clarify the pathogenesis and etiology, mainly in reproductive biotechnologies.

\section{REFERENCES}

AHMED, A.; JENA, B.; MISHRA, G.; TIWARI. R. A rare case of congenital dicephalic iniodymus defect in nondescript caprine neonate. Livest. Sci., v.6, p.10-12, 2015.

BÄHR, C.; BEINEKE, A.; DRÖGEMÜLLER, C.; DISTL, O. Diprosopus bei Kälbern verschiedener Rassen [Diprosopus in calves of different breeds]. Dtsch. Tierarztl. Wochenschr., v.111, p.154-158, 2004.

BIASIBETTI, E.; D'ANGELO, A.; BELLINO, C. et al. Diprosopia/dicephalia in Calves in Northern Italy: clinical and aetio- pathological features. Anat. Histol. Embryol., v.40, p.433-440, 2011.

BRANCO, E.F.C.; MATTOS, G.M.D.; MENDES, A.F.; CASTILHO, C. Congenital defects in calves from embryos produced in vitro: case report. Vet. Zootec., v.24, p.239-244, 2017.

FARIN, PW.; PIEDRAHITA, JA.; FARIN, CE. Development of fetuses and placentas from in vitro-produced bovine embryos. Theriogenelogy, v.65, p.178-91, 2006.

GÜLBAHAR, M.Y.; YÜKSEL, H.; SOYGÜDER, Z.; ERÇIN, Ö.F. Dicephalus, Arnold-Chiari malformation, spinal dysraphism and other associated anomalies in a newborn
Holstein calf. Turk. J. Vet. Anim. Sci., v.29, p.565-570, 2005.

HIRAGA， T.; ABE， M.; IWASA， K.; TAKE- HANA, K. Anatomical investigation of 39 cases of congenital duplication in calves. Congen Anomal., v.29, p.139-149, 1989.

MADARAME, H.; ITO, N.; TAKAI, S. Dicephalus, Arnold- Chiari malformation and spina bifida in a Japanese black calf. J. Vet. Med., v.40, p.155-160, 1993.

MAZZULLO, G.; GERMANA, A.; DE VICO, G.; GERMANA, G. Diprosopiasis in a lamb. A case report. Anat. Histol. Embryol., v.32, p.6062, 2003.

MEHMOOD, M.U.; ABBAS, W.; JABBAR, A. et al. An iniodymus dicephalic buffalo neonate. J. Anim. Plant. Sci., v.24, p.973-975, 2014.

SALAMI, O.; OKAIYETO, S.O.; DANBIRNI, S. et al. A case of diprosopus monauchenos in a day old calf (White Fulani Friesian cross) in an integrated dairy farm. Int. J. Livest. Prod., v.2, p.55-58, 2011.

SCHULZE, U.; KUIPER, H.; DOELEKE, R. et al. Familial occurrence of diprosopus in German Holstein calves. Berl. Munch. Tierarztl. Wochenschr., v.119, p.251-257, 2006.

TORRES, A.A.A.; LHAMAS, C.L.; MACORIS, D.G. et al. Macroscopic and microscopic findings in a set of congenital anomalies in two calves produced through in vitro production. Braz. J. Vet. Pathol., v.6, p.65-68, 2013.

VILČEK, Š.; HERRING, A.J.; HERRING, J.A. et al. Pestiviruses isolated from pigs, cattle and sheep can be allocated into at least three genogroups using polymerase chain reaction and restriction endonuclease analysis. Arch. Virol., v.136, p.309-323, 1994. 